$$
\begin{aligned}
& 3 B 107 \\
& . G 7
\end{aligned}
$$




\section{Hollinger Corp.}

$$
\text { pH } 8.5
$$




\title{
. $\mathrm{G7}$
}

Copy 1

[From the AMERICAN JOURNal CF SO FNCE. VOL. XLII, OCTOBER, 1891.]

USEFUL PLANTS OF THE FUTURE.

\author{
SOME OF THE
}

\section{POSSIBILITIES OF ECONOMIC BOTANY.}

By George Lincoln Goodale, Cambridge, Mass.

1891 



\section{With Compliments of the Author.}

Dr. Goodale ventures to ask his correspondents to send him any facts of interest regarding the local or exceptional uses of any plants, especially of those wild plants which have not yet found. a place in the economic lists. 



\title{
USEFUL PLANTS OF THE FUTURE.
}

\author{
SOME OF THE
}

\section{Possibilities of Economic Botany.}

The Presidential Address for 1891,

Before the American Association for the Advancement of Science, at the Washington meeting.

By George Lincoln Goodale, M.D., LL.D.,

Fisher Professor of Natural History in Harvard University, Cambridge, Mass.

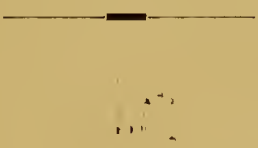

NEW HAVEN :

TUTTLE, MOREHOUSE \& TAYLOR, PRINTERS,

1891 , 
$S 3107$

G7

In Exchango

mich unir.

18 \& 4

$$
\because \vdots \vdots
$$


[From the American Journal of Science, Vol. XLII, October, 1891.]

\section{ARt. XXVII.-Some of the Possibitities of Economic Botany; by George Lincoln Goodale.}

[Presidential address delivered before the American Association for the Advancement of Science, at Washington, August, 1891.]

OUর Association demands of its president, on his retirement from office, some account of matters connected with the department of science in which he is engaged.

But you will naturally expect that, before I enter upon the discharge of this duty, I should present a report respecting the mission with which you entrusted me last year. You desired me to attend the annual meeting of the Anstralasian Association for the Adrancement of Science, and express your good wishes for its success. Compliance with your request did not necessitate any material change in plans formed long ago to visit the South Seas; some of the dates and the sequence of places had to be modified; otherwise the early plans were fully carried out.

I can assure you that it seemed very strange to reverse the seasons, and find mid-summer in January. But in the meeting with our brethren of the southern hemisphere, nothing else was reversed. The official welcome to your representative was as cordial, and the response by the members was as kindly as that which the people in the northern hemisphere would give to any fellow-worker coming from beyond the sea.

The meeting to which I was commissioned was held in January last in the Cathedral city of Christchurch, New Zealand, the seat of Canterbury College. 
Considering the distance between the other colonies and New Zealand, the meeting was well attended. From Hobart, Tasmania, to the southern harbor, known as the Bluff, in New Zealand, the sea voyage is only a little short of one thousand niles of rough water. From Sydney in New South Wales to Auckland, New Zealand, it is over twelve hundred miles. If, therefore, one journeys from Adelaide in Sonth Australia, to Christchurch, New Zealand, where the meeting was held he travels by land and by sea over two thousand miles. From Brisbane in Queensland, it is somewhat farther. Although certain concessions are made to the members of the Association, the fares by rail and by steamship are high, so that a journey from any one of the seats of learning in Australia proper to New Zealand is formidable on account of its cost. It is remarkable that so large a number of members should have met together under such circumstauces, and it speaks well for the great strength and vigor of the Association.

The Australasian Assuciation is modelled rather more closely after the British Association than is our own. The president delivers his address upon his inauguration. There are no general business meetings, but all the details are attended to by an executive committee answering to our council ; none except the members and associates are invited to attend even the sectional meetings and there are some other differences between the three associations. The secretaries stated to me their conviction that their organization and methods are better adapted to their surroundings than ours would be, and all of their argnments seemed cogent. Although the Association has been in existence but three years, it has accomplished great good. It has brought together workers in different fields for conference and mutual benefit; it has diminished misunderstandings, and has strengthened friendships. In short it is doing the same kind of good work that we believe ours is now doing, and in much the same way.

Your message was delivered at the general evening session immediately before the induction of the new officers. The retiring president, Baron von Mueller, and the incoming president Sir James Hector, in welcoming your representative, expressed their pleasure that you shonld have seen fit to send personal greetings.

In replying to their welcome, I endeavored to convey your felicitations upon the pronounced success of the Association, and your best wishes for a prosperous future. In your name, I extended a cordial invitation to the members to gratify us by their presence at some of our anuual meetings, and I have good reason to believe that this invitation will be accepted. I know it will be most thoronghly and hospitably honored by us. 
On the morning of the session to which I refer, we received in the daily papers, a cable telegram relative to the Bering Sea difficulties (which were then in an acute stage). In your stead, I ventured to say, "In these days of disquieting dispatches, when there are rumors of trouble between Great Britain, and the United States, it is pleasant to think that 'blood is thicker than water.'" This utterance was taken to mean that we are all English-speaking kinsmen, and even before I had finished, the old proverb was received with prolonged applause.

The next meeting of the Australasian Association is to be held in Hobart, the capital of Tasmania, under the presidency of the governor, Sir Robert Hamilton. The energetic secretaries Professor Liversidge, Professor Hutton and Mr. Morton, promise a cordial welcome to any of our members visiting the Association. Should you accept the invitation, you will enjoy every feature of the remarkable island, Tasmania, where the meeting is to be held. You will be delighted by Tasmanian scenery, vegetation and climate, but that which will give you the greatest enjoyment in this as in other English Sonth Sea colonies, is the fact that you are among English-speaking friends half way around the world. You will find that their efficient Association is devoted to the advancement of science and the promotion of sound learning. In short you will be made to feel at home.

The subject which I have selected for the valedictory address deals with certain industrial, commercial and economic questions: nevertheless it lies wholly within the domain of botany. I invite you to examine with me some of the possibilities of economic botany.

Of course, when treating a topic which is so largely specnlative as this, it is difficnlt and nnwise to draw a hard and fast line between possibilities and probabilities. Nowadays, possibilities are so often realized rapidly that they become accomplished facts before we are aware.

In asking what are the possibilities that other plants than those we now use may be utilized we enter upon a many-sided inquiry. ${ }^{*}$ Speculation is rife as to the coming man. May we not ask what plants the coming man will use?

There is an enormons disproportion between the total number of species of plants known to botanical science and the number of those which are employed by man.

The species of flowering plants already described and named are about one hundred and seven thousand. Acquisitions from unexplored or imperfectly explored regions may increase the

* For references, notes, etc., see p. 300 . 
aggregate perhaps one-tenth, so that we are within very safe limits in taking the number of existing species to be somewhat above one hundred and ten thousand. ${ }^{\prime}$

Now if we should make a comprehensive list of all the flowering plants which are cultivated on what we may call a fairly large scale at the present day, placing therein all food ${ }^{2}$ and forage plants, all those which are grown for timber and cabinet woods, for fibres and cordage, for tanning materials, dyes, resins, rubber, gums, oils, perfumes and medicines, we conld bring together barely three hundred species. If we should add to this short catalogue all the species, which without cultivation, can be used by man, we should find it considerably lengthened. A great many products of the classes just referred to are derived in commerce from wild plants, but exactly how much their addition would extend the list, it is impossible in the present state of knowledge to determine. Every enumeration of this character is likely to contain errors from two sources: first, it would be sure to contain some species which have outlived their real usefulness, and, secondly, owing to the chaotic condition of the literature of the subject, omissions would occur.

But after all proper exclusions and additions have been made, the total number of species of flowering plants utilized to any considerable extent by man in his civilized state does not exceed, in fact it does not quite reach, one per cent.

The disproportion between the plants which are known and those which are used becomes much greater when we take into account the species of flowerless plants also. Of the five hundred ferns and their allies we employ for other than decorative purposes only five; the mosses and liverworts, roughly estimated at tive hundred species, have only four which are directly used by man. There are comparatively few Algae, Fungi, or Lichens which have extended use.

Therefore, when we take the flowering and flowerless together, the percentage of utilized plants falls far below the estimate made for the flowering alone.

Such a ratio between the number of species known and the number used justifies the inquiry which I have proposed for discussion at this time-namely, can the short list of useful plants be increased to advantage? If so, how?

This is a practical question; it is likewise a very old one. In one form or another, by one people or another, it has been asked from early times. In the dawn of civilization, mankind inherited from savage ancestors certain plants, which had been found amenable to simple cultivation, and the products of these plants supplemented the spoils of the chase and of the sea. The question which we ask now was asked then. Wild 
plants were examined for new uses; primitive agriculture and horticulture extended their bounds in answer to this inquiry. Age after age has added slowly and cautiously to the list of cultivable and utilizable plants, but the aggregate additions have been as we have seen, comparatively slight.

The question has thus no charm of novelty, but it is as practical to-day as in early ages In fact, at the present time, in view of all the appliances at the command of modern science and under the strong light cast by recent biological and technological research, the inquiry which we propose assumes great importance. One phase of it is being attentively and systematically regarded in the great Experiment Stations, another phase is being studied in the laboratories of Chemistry and Pharmacy, while still another presents itself in the musenms of Economic Botany.

Onr question may be put in other words, which are even more practical. What present likelihood is there that our tables may, one of these days, have other regetables, fruits and cereals, than those which we use now? What chance is there that new fibers may supplement or even replace those which we spin and weave, that woven fabrics may take on new vegetable colors, that flower's and leaves may yield new perfumes and flavors? What probability is there that new remedial agents may be found among plants neglected or now wholly unknown? The answer which I shall attempt is not in the nature of a prophecy; it can claim no rank higher than that of a reasonable conjecture.

At the outset it must be said that synthetic chemistry has made and is making some exceedingly short cuts across this field of research, giving us artiticial dyes. odors, flavors, and medicinal substances, of such excellence that it sometimes seems as if before long the old-fashioned chemical processes in the plant itself would play only a subordinate part. But although there is no telling where the triumphs of chemical synthesis will end, it is not probable that it will ever interfere essentially with certain classes of economic plants. It is impossible to conceive of a synthetic fiber or a synthetic fruit. Chemistry gives us fruit-ethers and fruit-acids, and after a while may provide us with a true artificial sugar and amorphous starch; but artificial fruits worth the eating or artificial fiber's worth the spinning are not coming in our day.

Despite the extraordinary achievements of synthetic chemistry, the world must be content to accept for a long time to come, the results of the intelligent labor of the cultivator of the soil and the explorer of the forest. Improvement of the good plants we now utilize, and the discovery of new ones must remain the care of large numbers of diligent students 
and assiduous workmen. So that, in fact, our question resolves itself into this: can these practical investigators hope to make any substantial advance?

It will be well to glance first at the manner in which onr wild and cultivated plants have been singled ont for use. We shall, in the case of each class, allude to the methods by which the selected plants have been improved, or their products fully utilized. Thus looking the ground over, although not minutely, we can see what new plants are likely to be added to our list. Our illustrations can, at the best, be only fragmentary.

We shall not have time to treat the different divisions of the subject in precisely the proportions which would be demanded by an exhaustive essay; an address on an occasion like this must pass lightly over some matters which other opportunities for discussion could properly examine with great fulness. Unfortunately, some of the minor topics which must be thus passed by, possess considerable popular interest; one of these is the first subordinate question introductory to our task, namely, how were our useful cultivated and wild plants selected for use?

A study of the early history of plants employed for ceremonial purposes, in religions solemnities, in incantations, and for medicinal uses, shows how slender has sometimes been the claim of certain plants to the possession of any real utility. But some of the plants which have been brought to notice in these ways have afterwards been found to be utilizable in some fashion or other. This is often seen in the cases of the plants which have been suggested for medicinal use through the absurd doctrine of signatures. ${ }^{3}$

It seems clear that, except in modern times, nseful plants have been selected almost wholly by chance, and it may well be said that a selection by accident is no selection at all. Nowadays, the new selections are based on analogy. One of the most striking illustrations of the modern method is afforded by the ntilization of bamboo fiber for electric lamps.

Sonie of the classes of useful plants must be passed by without present discussion; others alluded to slightly, while still other groups fairly representative of selection and improvement will be more fully described. In this latter class would naturally come, of course, the food-plants known as

\section{The Cereals.}

Let us look first at these.

The species of grasses which yield these seed-like fruits, or as we might eall them for our purpose seeds, are numerous ; twenty of them are enltivated largely in the Old World, but 
only six of them are likely to be very familiar to you, namely, wheat, rice, barley, oats, rye and maize. The last of these is of American origin, despite doubts which have been cast upon it. It was not known in the Old World until after the discovery of the New. It has probably been very long in cultivation. The others all belong to the Old World. Wheat and barley have been cultivated from the earliest times; according to De Candolle, the chief authority in these matters. about four thousand years. Later came rye and oats, both of which have been known in cultivation for at least two thousand years. Even the shorter of these periods gives time enough for wide variation, and as is to be expected there are numerons varieties of them all. For instance, Vilmorin, in 1880, figured sixty-six varieties of wheat with plainly distinguishable characters. ${ }^{5}$

If the Chinese records are to be trusted, rice has been culti. vated for a period much longer than that assigned by our history and traditions to the other cereals, and the varieties are correspondingly numerous. It is said that in Japan above three hundred varieties are grown on irrigated lands, and more than one hundred on mplands. ${ }^{6}$

With the possible exception of rice, not one of the species of cereals is certainly known in the wild state. ${ }^{7} \mathrm{Now}$ and then specimens have been gathered in the East which can be referred to the probable types from which our varieties have sprung, but doubt has been thrown upon everyone of these cases. It has been shown conclusively that it is easy for a plant to escape from cultivation and persist in its new home even for a long time in a near approximation to cultivated form. Hence, we are forced to receive all statements regarding the wild forms with caution. But it may be safely said that if all the varieties of cereals which we now cultivate were to be swept out of existence, we could hardly know where to turn for wild species with which to begin again. We could not know with certainty.

To bring this fact a little more vividly to our minds, let us suppose a case. Let us imagine that a blight without parallel has brought to extinction all the forms of wheat, rice, rye, oats, barley and maize, now in cultivation, but without affecting the other grasses or any other form of vegetable food. Mankind wonld be obliged to subsist upon the other kindly fruits of the earth; upon root-crops, tubers, leguminous seeds, and so on. Some of the substitutions might be amusing in any other time than that of a threatened famine. Others would be far from appetizing under any condition, and only a few would be wholly satisfying even to the most pronounced vegetarian. In short, it would seem, from the first, that the cereals fill a place occupied by no other plants. The composition of the grains 
is theoretically and practically almost perfect as regards food ratio between the nitrogenous matters and the starch group; and the food value, as it is termed, is high. But aside from these considerations, it would be seen that for safety of preservation through considerable periods, and for convenience of transportation, the cereals take highest rank. Pressure would come from every side to compel us to find equivalents for the lost grains. From this predicament I believe that the wellequipped Experiment Stations and the Agricultural Departments in Europe and America would by and by extricate us. Continuing this hypothetical case, let us next inquire how the Stations would probably go to work in the up.hill task of making partially good a well-nigh irreparable loss.

The whole group of relatives of the lost cereals wonld be passed in strict review. Size of grain, strength and vigor and plasticity of stock, adaptability to different surroundings, and flexibility in variation would be examined with scrupulous care.

But the range of experiment would, under the circumstances, extend far beyond the relatives of our present cereals. It wonld embrace an examination of the other grasses which are even now cultivated for their grains, but which are so little known outside of their own limit, that it is a surprise to hear about them. For example, the Millets, great and small, would be investigated. These grains, so little known here, form an important crop in certain parts of the east. One of the leading authorities on the subject ${ }^{8}$ states that the Millets constitnte "a more important crop" in India "than either Rice or Wheat, and are grown more extensively, being raised from Madras in the south to Rajputana in the north. They occupy about eightythree per cent of the food-grain area in Bombay and Sinde, forty-one per cent in the Punjab, thirty-nine per cent in the Central Provinces," "in all about thirty million acres."

Having chosen proper subjects for experimenting, the cultivator's would make use of certain well-known principles. By simple selection of the more desirable seeds, strains would be secured to suit definite wants, and these strains would be kept as races, or attempts would be made to intensify wished-for characters. By skillful hybridizing of the first, second and higher orders, tendencies to wider variation would be obtained and the process of selection considerably expedited. ${ }^{9}$

It is ont of our power to predict how much time would elapse before satisfactory substitutes for our cereals conld be found. In the improvement of the grains of grasses other than those which have been very long under cultivation, experiments have been few, scattered and indecisive. Therefore we are as badly off for time-ratios as are the geologists and archæologists, in their statements of elapsed periods. It is 
impossible for us to ignore the fact that there appear to be occasions in the life of a species when it seems to be peculiarly susceptible to the influences of its surroundings. ${ }^{10}$ A species, like a carefully laden ship, represents a balaneing of forces within and without. Disturbance may come through variation from within, as from a shifting of the cargo, or, in some cases from without. We may suppose both forces to be active in producing variation, a change in the internal condition rendering the plant more susceptible to any change in its surronndings. Under the influence of any marked disturbance, a state of unstable equilibrinm may be brought about, at which times the species as such is easily acted upon by very slight agencies.

One of the most marked of these derangements is a consequent of cross-breeding within the extreme limits of varieties. The resultant forms in such cases can persist only by close breeding or by propagation from buds or the equivalents of buds. Disturbances like these arise unexpectedly in the ordinary course of nature, giving us sports of various kinds. These critical periods however, are not unwelcome, since skillful cultivators can take advantage of them. In this very tield much has been accomplished. An attentive study of the sagacious work done by Thomas Andrew Knight shows to what extent this can be done. ${ }^{11}$ But we must confess that it would be absolntely impossible to predict with certainty how long or how short would be the time before new cereals or acceptable equivalents for them would be provided. Upheld by the confidence which I have in the intelligence, ingenuity, and energy of our Experiment Stations, I may say that the time would not probably exceed that of two generations of our race, or half a century.

In now laying aside our hypothetical illustration, I venture to ask why it is that our Experiment Stations and other institutions dealing with plants and their improvement, do not undertake investigations like those which I have sketched? Why are not some of the grasses other than our present cereals studied with reference to their adoption as food grains? One of these species will naturally suggest itself to you all, namely, the Wild Rice of the Lakes. ${ }^{12}$ Observations have shown that, were it not for the difficulty of harvesting these grains which fall too easily when they are ripe, they might be utilized. But attentive search might find or educe some variety of Zizania, with a more persistent grain and a better yield. There are two of our sea-shore grasses which have excellent grains, but are of small yield. Why are not these, or better ones which might be suggested by observation, taken in haud? 
The reason is plain. We are all content to move along in lines of least resistance, and are disinclined to make a fresh start. It is merely leaving well enough alone, and so far as the cereals are concerned it is indeed well enough. The generous grains of modern varieties of wheat and barley compared with the well-preserved charred vestiges found in Greece by Schliemann, ${ }^{28}$ and in the lake-dwellings, ${ }^{14}$ are satisfactory in every respect. Improvements, however, are making in many directions; and in the cereals we now have, we possess far better and more satisfactory material for further improvement both in quality and as regards range of distribution than we could reasonably hope to have from other grasses.

From the cereals we may turn to the interesting groups of plants comprised under the general term

\section{Vegetaklis.}

Under this term it will be convenient for us to include all plants which are employed for culinary purposes, or for table use such as salads and relishes.

The potato and sweet potato, the pumpkin and squash, the red or capsicum peppers, and the tomato, are of American origin.

All the others are, most probably, natives of the Old World. Only one plant coming in this class has been derived from Southern Australasia, namely, New Zealand Spinach, (Tetragonia.

Among the vegetables and salad-plants longest in cultivation we may enumerate the following-turnip, onion, cabbage, purslane, the large bean (Faba), chick-pea, lentil and one species of pea, garden pea. To these an antiquity of at least four thousand years is ascribed.

Next to these, in point of age, come the radish, carrot, beet, garlic, garden cress, and celery, lettuce, asparagus and the leek. Three or four leguminons seeds are to be placed in the same eategory, as are also the black peppers.

Of more recent introduction the most prominent are, the parsnip, oyster plant, parsley, artichoke, endive and spinach.

From these lists I bave purposely omitted a few which belong exclusively to the tropies, such as certain yams.

The number of varieties of these vegetables is astounding. It is, of course, impossible to discriminate between closely allied varieties which have been introduced by gardeners and seedsmen under different names, but which are essentially identical, and we must therefore have recourse to a conservative authority, Vilmorin, ${ }^{15}$ from whose work a few examples have been selected. The varieties which he accepts are suf- 
ficiently well distinguished to admit of description and in most instances of delineation, without any danger of confusion. The potato has, he says, innumerable varieties, of which he accepts forty as easily distinguishable and worthy of a place in a general list, but he adds also a list, comprising, of course, synonyms, of thirty-two French, twenty-six English, nineteen Âmerican and eighteen German varieties. The following numbers speak for themselves, all being selected in the same careful manner as those of the potato: celery more than twenty; carrot more than thirty; beet, radish and potato more than forty; lettuce and onion more than tifty; turnip more than seventy; cabbage, kidney bean and garden pea more than one hundred.

The amount of horticultural work which these numbers represent is enormous. Each variety established as a race (that is a variety which comes true to seed) has been evolved by the same sort of patient care and waiting which we have seen is necessary in the case of cereals. but the time of waiting has not been as a general thing so long.

You will permit me to quote from Vilmorin ${ }^{16}$ also an account of a common plant, which will show how wide is the range of variation and how obscure are the indications in the wild plant of its available possibilities. The example shows how completely hidden are the potential variations useful to mankind.

"Cabbage, a plant which is indigenous in Europe and Western Asia, is one of the vegetables which has been cultivated from the earliest time. The ancients were well acquainted with it, and certainly possessed several varieties of the head-forming kinds. The great antiquity of its culture may be inferred from the inmense number of varieties which are now in existence, and from the very important modifications which have been produced in the characteristics in the original or parent plant.

The wild Cabbage, such as it now exists on the coasts of England and France, is a perennial plant with broad-lobed, undulated, thick, smooth leaves, covered with a glancous bloom., The stem attains a height of from nearly two and a half to over three feet, and bears at the top a spike of yellow or sometimes white flowers. All the cultivated varieties present the same peculiarities in their inflorescence, but up to the time of flowering they exhibit most marked differences from each other and from the original wild plant. In most of the Cabbages, it is chiefly the leaves that are developed by cultivation; these for the most part become imbricated or overlap one another closely, so as to form a more or less compact head, the heart or interior of which is composed of the central undeveloped shoot and the younger leaves next it. The shape of the head is spherical, sometimes flattened, sometimes conical. All the varieties which form heads in this way are known by the general name of Cabbages, while other kinds with 
large branching leaves which never form heads are distinguished by the name of Borecole or Kale.

In some kinds, the flower-stems have been so moditied by culture as to become transformed into a thick, fleshy tender mass, the growth and enlargement of which are produced at the expense of the flowers which are absorbed and rendered abortive. Such are the Broccolis and Cauliflowers."

\section{But this plant has other transformations.}

"In other kinds, the leaves retain their ordinary dimensions, while the stem or principal root has been brought by cultivation to assume the shape of a large ball or turnip, as in the case of the plants known as Kohl-Rabi and Turnip-rooted Cabbage or Swedish Turnip. And lastly, there are varieties in which cultivation and selection have produced modifications in the ribs of the leaves, as in the Couve Tronchuda, or in the axillary shoots (as in Brussels sprouts), or in several organs together, as in the Marrow Kales, and the Neapolitan Curled Kale."

Here are important morphological changes like those to which Professor Bailey has called attention in the case of the tomato.

Suppose we are strolling along the beach at some of the seaside resorts of France, and should fall in with this coarse cruciferous plant, with its sprawling leaves and strong odor. Would there be anything in its appearance to lead us to search for its hidden merit as a food plant? What conld we see in it which wonld give it a preference over a score of other plants at onr feet? Again, suppose we are journeying in the high lands of Peru, and should meet with a strong-smelling plant of the Night-shade family, bearing a small irregular fruit, of subacid taste and of peculiar flavor. We will further imagime that the peculiar taste strikes our fancy, and we conceive that the plant has possibilities as a sonrce of food. We should be led by our knowledge of the potato. probably a native of the same region, to think that this allied plant might be safely transferred to a northern climate, but would ther'e be promise of enough future usefulness in such a case as this, to warrant our carrying the plant North as an article of food? Suppose, further, we shonld ascertain that the fruit in question was relished not only by the natives of its home, but that it had found favor among the tribes of South Mexico and Central America, and had been cultivated by them until it had attained a large size; should we be strengthened in our venture? Let us go one step further still. Suppose that having decided upon the introduction of the plant, and having urged everybody to try it, we should find it discarded as a fruit, but taking a place in gardens as a curiosity under an absurd name, or as a basis 
for preserves and pickles; should we not look npon our experiment in the introduction of this new plant as a failure? This is not a hypothetical case.

The Tomato, ${ }^{17}$ the plant in question, was cultivated in Enrope as long ago as $1554 j^{18}$ it was known in Virginia in 1781 and in the Northern States in 1785 ; but it found its way into favor slowly, even in this land of its origin. A credible witness states that in Salem it was almost impossible to induce people to eat or even taste of the fruit. And yet, as you are well aware, its present cultivation on an enormous scale in Europe and this country is scarcely sufficient to meet the increasing demand.

A plant which belongs to the family of the tomato has been known to the public under the name of the strawberry tomato. The juicy yellow or orange-colored fruit is enclosed in a papery calyx of large size. The descriptions which were published when the plant was placed on the market were attractive, and were not exaggerated to a misleading extent. But, as you all know, the plant never gained any popularity. If we look at these two cases carefully we shall see that what appears to be caprice on the part of the public is at bottom common sense. The cases illustrate as well as any which are at command, the difficulties which surround the whole subject of the introduction of new foods.

Before asking specifically in what direction we shall look for new vegetables I must be pardoned for calling attention, in passing, to a very few of the inany which are already in limited use in Europe and this country, but which merit a wider employment. Cardon, or Cardoon; Celeriac, or turnip-rooted celery; Fetticus, or corn-salad; Martynia; Salsify ; Sea-kale ; and nnmerous small salads, are examples of neglected treasures of the vegetable garden.

The following which are even less known may be mentioned as fairly promising. ${ }^{19}$

(1) Arracacia esculenta, called Arracacha, belonging to the Parsley family. It is extensively cultivated in some of the northern States of Sonth America. The stems are swollen near the base, and produce tuberons enlargements filled with an excellent starch. Although the plant is of comparatively easy cultivation, efforts to introduce it into Europe have not been successful, but it is said to have found favor in both the Indies, and may prove useful in our Southern States.

(2) Ollucus or Ollncus, another tuberons-rooted plant from nearly the same region, but belonging to the Beet or Spinach family: It has produced tubers of good size in England, but they are too waxy in consistence to dispute the place of the better tubers of the potato. The plant is north investigating for our hot dry lands. 
(3) A tuber-bearing relative of our common Hedge-nettle, or Stachys, is now cultivated on a large scale at Crosnes in France, for the Paris market. Its name in Paris is taken from the locality where it is now grown for use. Although its native country is Japan, it is called by some seedsmen Chinese Artichoke. At the present stage of cultivation, the tubers are small and are rather hard to keep, but it is thought "that both of these defects can be overcome or evaded." ${ }^{21}$ Experiments indicate that we have in this species a valuable addition to our vegetables. We must next look at certain other neglected possibilities.

Dr. Edward Palmer, ${ }^{20}$ whose energy as a collector and acuteness as an observer are known to yon all, has brought together very interesting facts relative to the food-plants of our North American aborigines. Among the plants described by him there are a few which merit careful investigation. Against all of them, however, there lie the objections mentioned before, namely:

(1) The long time required for their improvement, and

(2) The difficulty of making them acceptable to the community, involving

(3) The risk of total and mortifying failure.

In the notes to this address the more prominent of these are enumerated.

In 1854 the late Professor Gray called attention to the remarkable relations which exist between the plants of Japan and those of our Eastern coast. You will remember that he not only proved that the plants of the two regions had a common origin, but also emphasized the fact that many species of the two countries are almost identical. It is to that country which has yielded us so many useful and beautiful plants that we turn for new vegetables to supplement our present food-resources. One of these plants, namely, Stachys, has already been mentioned as rather promising. There are others which are worth examination and perhaps acquisition.

One of the most convenient places for a preliminary examination of the vegetables of Japan is at the railroad stations on the longer lines, for instance, that running from Tokio to Kobe. For native consumption there are prepared luncheon boxes of two or three stories, provided with the simple and yet embarrassing chop-sticks. It is worth the shock it causes one's nerves to invest in these boxes and try the vegetable contents. The bits of fish, flesh and fowl which one finds therein can be easily separated and discarded, upon which there will remain a few delicacies. The pervading odor of the box is that of aromatic vinegar. The generous portion of boiled rice is of excellent quality with every grain well softened and distinct, and this 
without anything else would suffice for a tolerable meal. In the boxes which have fallen under my observation there were sundry boiled roots, shoots and seeds which were not recognizable by me in their cooked form. Professor Georgeson, ${ }^{22}$ formerly of Japan, has kindly identified some of these for me, but he says "there are doubtless many others used occasionally."

One may find sliced Lotus roots, roots of large Burdock, Lily bulbs, shoots of Ginger, pickled green Plums, beans of many sorts, boiled Chestnuts, nuts of the Gingko tree, pickled greens of various kinds, dried cucumbers, and several kinds of seaweeds. Some of the leaves and roots are cooked in much the same manner as beet-roots and beet-leaves are by ns, and the general effect is not unappetizing. The boiled shoots are suggestive of only the tougher ends of asparagus. On the whole, I do not look back on Japanese railway luncheons with any longing which would compel me to advocate the indiscriminate introduction of the constitnent vegetables here.

But when the same vegetables are served in native inns, under more favorable culinary conditions, without the flavor of vinegar and of the pine wood of the luncheon boxes, they appear to be worthy of a trial in our horticulture, and I therefore deal with one or two in greater detail.

Professor Georgeson, whose advantages for acquiring a knowledge of the useful plants of Japan have been unusually good, has placed me under great obligations by communicating certain facts regarding some of the more promising plants of Japan which are not now nsed here. It should be said that several of these plants have already attracted the notice of the Agricultural Department in this comntry.

The Soy Bean (Glycine hispida). This species is known here to some extent, but we do not have the early and best varieties. These beans replace meat in the diet of the common people.

Mucuna (Mucuna capitata) and Dolichos (Dotichos cultratus) are pole beans possessing merit.

Dioscorew; there are several varieties with palatable roots. "Years ago one of these was spoken of by the late Dr. Gray, as possessing "excellent roots, if one could only dig them."

Colocasia antiquorum has tuberous roots, which are nutritious.

Conophallus Konjak has a large bulbous root, which is sliced, dried and beaten to a powder. It is an ingredient in cakes.

Aratia cordata is cultivated for the shoots, and nsed as we use Asparagus.

Enanthe stolonifera and Cryptotcenia Canadensis are palatable salad plants, the former being used also as greens. 
There is little hope, if any, that we shall obtain from the hotter climates for our southern territory new species, of merit. The native markets in the tropical cities, like Colombo, Batavia, Singapore and Saigon, are rich in fruits, but outside of the native plants bearing these, nearly all the plants appear to be wholly in established lines of cultivation, such, for instance, as members of the Gourd and Night-shade families.

Before we leave the subject of our coming vegetables, it will be well to note a naïve-caution enjoined by Vilmorin in his work, Les Plantes Potagères. ${ }^{23}$

"Finally," he says, "we conclude the article devoted to each plant with a few remarks on the uses to which it may be applied and on the parts of the plants which are to be so used. In many eases such remarks may be looked upon as idle words, and yet it would sometimes have been useful to have them when new plants were cultivated by us for the first time. For instance, the giant edible Burdock of Japan (Lappa edulis) was for a long time served up on our tables only as a wretchedly poor Spinach, because people would cook the leaves, whereas, in its native country, it is only cultivated for its tender fleshy roots."

I trust you are not discouraged at this outlook for our coming vegetables.

Two groups of improvable food-plants may be referred to before we pass to the next class, namely, edible fungi and the beverage plants. All botanists who have given attention to the matter agree with the late Dr. Curtis of North Carolina that we have in the unutilized mushrooms an immense amount of available nutriment of a delicious quality. It is not improbable that other" fungi than onr common "edible mushroom" will by and by be subjected to careful selection.

The principal beverage-plants, Tea, Coffee and Chocolate, are all attracting the assiduous attention of cultivators. The first of these plants is extending its range at a marvellous rate of rapidity through India and Ceylon; the second is threatened by the pests which have almost exterminated it in Ceylon, but a new species, with crosses therefrom, is promising to resist them successfully; the third, Chocolate, is every year passing into lands farther from its original home. To these have been added the Kola, of a value as yet not wholly determined, and others are to augment the short list.

\section{Fruts.}

Botanically speaking, the cereal grains of which we have spoken, are true fruits, that is to say, are ripened ovaries, but for all practical purposes they may be regarded as seeds. The 
fruits, of which mention is now to be made, are those commonly spoken of in our markets, as frnits.

First of all, attention must be called to the extraordinary changes in the commercial relations of fruits by two direct causes,

(1) The canning industry, and

(2) Swift transportation by steamers and railroads.

The effects of these two agencies are too well known to require more than this passing mention. By them the fruits of the best fruit-growing countries are carried to distant lands in quantities which surprise all who see the statistics for the first time. The ratio of increase is very startling. Take for instance, the figures given by Mr. Morris at the time of the great Colonial and Indian Exhibition, in London. Compare double decades of years.

$$
\begin{aligned}
& 1845, \quad £ 886,888 . \\
& 1865, £ 3,185,984 . \\
& 1885, £ 7,587,523 .
\end{aligned}
$$

In the Colonial Exhibition at London, in 1886, fruits from the remote colonies were exhibited under conditions which proved that, before long, it may be possible to place such delicacies as the Cherimoyer, the Sweet-cup, Sweet-sop, Rambutan, Mango and Mangosteen, at even onr most northern seaports. Furthermore, it seems to me likely that with an increase in our knowledge with regard to the microbes which produce decay, we may be able to protect the delicate fruits from injury for any reasonable period. Methods which will supplement refrigeration are sure to come in the very near future, so that even in a conntry so vast as our own, the most perishable fruits will be transported throngh its length and breadth without harm.

The canning industry and swift transportation are likely to diminish zeal in searching for new fruits, since, as we have seen in the case of the cereals, we are prone to move in lines of least resistance and leave well enough alone.

To what extent are onr present fruits likely to be improved? Even those who have watched the improvement in the quality of some of our fruits, like oranges, can hardly realize how great has been the improvement within historic times in the character of certain pears, apples, and so on.

The term historic is nsed advisedly, for there are pre-historic fruits which might serve as a point of departure in the consideration of the question. In the ruins of the lake-dwellings in Switzerland, ${ }^{24}$ charred apples have been found, which are 
in some cases, plainly of small size, hardly equalling ordinary crab apples. But, as Dr. Sturtevant has shown, in certain directions, there has been no marked change of type, the change is in quality.

In comparing the earlier descriptions of fruits with modern accounts it is well to remember that the high standards by which fruits are now judged are of recent establishment. Fruits which would once have been esteemed excellent, would to-day be passed by as unworthy of regard

- It seems probable that the list of seedless fruits will be materially lengthened, provided our experimental horticulturists nake use of the material at their command. The common frnits which have very few or no seeds are the banana, pineapple and certain oranges. Others mentioned by Mr. Darwin as well known are the bread-fruit, pomegranate, azarole or Neapolitan medlar, and date palms. In commenting upon these fruits, $\mathrm{Mr}$. Darwin ${ }^{25}$ says that most horticulturists "look at the great size and anomalous development of the fruit as the cause and sterility as the result," but he holds the opposite view as more probable, that is, that the sterility, coming about gradually, leaves free for other growth the abundant supply of building material which the forming seed would otherwise have. He adınits, however, that "there is an antagonism between the two forms of reproduction, by seeds and by buds when either is carried to an extreme degree which is independent of any incipient sterility."

Most plant-hybrids are relatively infertile, but by no means wholly sterile. With this sterility there is generally augmented vegetative vigor, as shown by Nägeli. Partial or complete sterility and corresponding luxuriance of root, stem, leaves and flower, may come about in other obscure ways, and such cases are familiar to botanists. ${ }^{10}$ Now it seems highly probable that either by hybridizing directed to this special end, or by careful selection of forms indicating this tendency to the correlated changes, we may succeed in obtaining important additions to our seedless or nearly seedless plants. Whether the ultimate profit would be large enough to pay for the time and labor involved is a question which we need not enter into; there appears to me no reasonable doubt that such efforts would be successful. There is no reason in the nature of things why we should not have strawberries without the so-called seeds; blackberries and raspberries, with only delicious pulp; and large grapes as free from seeds as the small ones which we call "currants" but which are really grapes from Corinth.

These and the coreless apples and pears of the future, the stoneless cherries and plums, like the common fruits before 
mentioned must be propagated by bud division, and be open to the tendency to diminished strength said to be the consequence of continued bud-propagation. But this bridge need not be crossed until we come to it. Bananas have been perpetuated in this way for many centuries, and pineapples since the discovery of America, so that the borrowed trouble alluded to is not threatening. First we must catch our seedless fruits.

Which of our wild fruits are promising subjects for selection and cultivation?

Mr. Crozier of Michigan has pointed out ${ }^{28}$ the direction in which this research may prove most profitable. He enumerates many of our small fruits and nuts which can be improved.

Another of our most careful and successful horticulturists believes that the common blueberry and its allies are very suitable for this purpose and offer good material for experimenting. The sugar-plum, or so-called shadbush, has been improved in many particulars, and others can be added to this list.

But again we turn very naturally to Japan, the country from which our gardens have received many treasures. Referring once more to Professor Georgeson's studies, ${ }^{27}$ we must mention the varieties of Japanese apples, pears, peaches, plums, cherries and persimmons. The persimmons are already well-known in some parts of our country, under the name "kaki" and they will donbtless make rapid progress in popular favor.

The following are less familiar: Actinidia arguta and volubilis, with delicious berries;

Stauntonia, an evergreeen vine yielding a palatable fruit;

Myrica rubra, a small tree with an acidulons juicy fruit;

Elocagnus umbellata, with berries for preserves.

The active and discriminating horticnltural journals in America and Europe are alive to the possibilities of new Japanese fruits, and it cannot be very long before our list is considerably increased.

It is absolutely necessary to recollect that in most cases variations are slight. Dr. Masters and Mr. Darwin have called attention to this and have adduced many illustrations, all of which show the necessity of extreme patience and caution. The general student curious in such matters can have hardly any task more instructive than the detection of the variations in such common plants as the blueberry, the wild cherry, or the like. It is an excellent preparation for a practical study of the variations in our wild fruits suitable for selection.

It was held by the late Dr. Gray that the variations in nature by which species have been evolved were led along nseful lines, a view which $\mathrm{Mr}$. Darwin regretted he could not enter. tain. However this may be, all acknowledge that by the hand 
of the cultivator variations can be led along useful lines; and furthermore the hand which selects must uphold them in their unequal strife. In other words it is one thing to select a variety and another to assist it in maintaining its hold npon existence. Without the constant help of the cultivator who selects the useful variety, there comes a reversion to the ordinary specific type which is fitted to cope with its surroundings.

I think you can agree with me that the prospect for new fruits and for improvements in our established favorites is fairly good.

\section{Timbers and Cabinet Woods.}

Can we look for new timbers and cabinet woods? Comparatively few of those in common use are of recent introduction. Attempts have been made to bring into great prominence some of the excellent trees of India and Australia which furnish wood of much beauty and timber of the best quality. A large proportion of all the timbers of the South Seas are characterized by remarkable firmness of texture and high specific gravity. ${ }^{28}$ The same is noticed in many of the woods of the Indies. A few of the heavier and denser sorts, like Jarrah, of West Australia, and Sabicu of the Caribbean Islands, have met with deserved favor in England, but the cost of transportation militates against them. It is a fair question whether, in certain parts of our country, these trees and others which can be utilized for veneers, may not be cultivated to advantage. Attention should be again called to the fact that many plants succeed far better in localities which are remote from their origin but where they find conditions substantially like those which they have left. This fact, to which we must again refer in detail with regard to certain other classes of plants, may have some bearing upon the introduction of new timber trees. Certain drawbacks exist with regard to the timber of some of the more rapidly growing hard-wood trees which have prevented their taking a high place in the scale of values in mechanical engineering.

One of the most useful soft-wooded trees in the world is the Kauri. It is restricted in its range to a comparatively small area in the North Island of New Zealand. It is now being cut down with a recklessness which is as prodigal and shameful as that which has marked our own treatment of forests here. "It should be said, however, that this destruction is under protest, in spite of which it would seem to be a qnestion of only a few years when the great Kauri groves of New Zealand will be a thing of the past. Our energetic Forest Department has on its hands problems just like this which perplexes one of the new lands of the South. The task in 
both cases is double: to preserve the old treasures and to bring in new.

The energy shown by Baron von Mueller, the renowned Government Botanist of Victoria and by various Forest departments in encouraging the cultivation of timber trees will assuredly meet with success; one can hardly hope that this success will appear fully demonstrated in the lifetime of those now living, but I cannot think that many years will pass before the promoters of such enterprises may take fresh courage.

In a modest structnre in the City of Sydney, New South Wales, Mr. Maiden ${ }^{28}$ has brought together, under great difficulties, a large collection of the nseful products of the vegetable kingdom as represented in Australia. It is impossible to look at the collection of woods in that Museum or at the similar. and more showy one in Kew, without believing that the field of forest culture must receive rich material from the Southern hemisphere.

Before leaving this part of our snbject, it may be well to take some illustrations in passing, to show how important is the influence exerted upon the ntilization of vegetable products by causes which may, at first, strike one as being rather remote.

(1) Photography makes nse of the effect of light on chromatized gelatin to produce under a negative the basis of relief plates for engraving. The degree of excellence reached in moditications of this simple device has distinctly threatened the very existence of wood engraving, and hence follows a diminished degree of interest in box-wood and its substitutes.

(2) Iron, and in its turn steel, is used in ship-building and this renders of greatly diminished interest all questions which concern the choice of the different oaks, and similar woods:

(3) But on the other hand there is increased activity in certain directions, best illustrated by the extraordinary develment of the chemical methods for manufacturing wood pulp. By the improved processes, strong tibers suitable for fine felting on the screen and fit for the best grades of certain lines of paper are given to us from rather inferior sorts of wood. He would be a rash prophet who should venture to predict what will be the future of this wonderful industry, but it is plain that the time is not far distant when acres now worthless may be covered by trees under cultivation growing for the pulpmaker.

There is no department of Economic Botany more promising in immediate results than that of Arboriculture.

\section{Vegetable Fibers.}

The vegetable fibers known to commerce are either plant hairs, of which we take cotton as the type, or tilaments of 
bast-tissue, represented by flax. No new plant hairs have been suggested which can compete in any way for spinning with those yielded by the species of Gossypium, or cotton, but experiments more or less systematic and thorough are being carried on with regard to the improvement of the varieties of the species. Plant hairs for the stuffing of cushions and pillows need not be referred to in connection with this subject.

Countless sorts of plants have been suggested as sources of good bast-fibers for spinning and for cordage, and many of these make capital substitutes for those already in the factories. But the questions of cheapness of production, and of subsequent preparation for use, have thus far militated against success. There may be much difference between the profits promised by a laboratory experiment and those resulting from the same process conducted on a commercial scale. The existence of such differences has been the rock on which many enterprises seeking to introduce new fibers have been wrecked.

In dismissing this portion of our subject it may be said that a process for separating fine fibers from undesirable structural elements and from resin-like substances which accompany them, is a great desideratum. If this were supplied, many new species would assume great prominence at once.

\section{Tanning Materials.}

What new tanning materials can be confidently sought for? In his "Useful Native Plants of Australia," Mr. Maiden" describes over thirty species of "Wattles" or Acacias, and about half as many Eucalypts, which have been examined for the amount of tanning material contained in the bark. In all, 87 Australian species have been under examination. Besides. this, much has been done looking in the same direction at the suggestion and under the direction of Baron von Mueller, of Victoria. This serves to indicate how great is the interest in this subject, and how wide is the field in our own country for the introduction of new tanning plants.

It seems highly probable, however, that artificial tanning substances will at no distant day replace the crude matters now employed.

\section{Resins, Etc.}

Resins, oils, gums and medicines from the vegetable kingdom would next engage our attention if they did not seem rather too technical for this occasion, and to possess an interest on the whole somewhat too limited. But an allied substance may serve to represent this class of products and indicate the drift of present research. 
India Rubber. ${ }^{19}$-Under this term are included numerons substances which possess a physical and chemical resemblance to each other. An Indian Ficns, the early source of supply, soon became inadequate to furnish the quantity used in the arts even when the manipulation of rubber was almost nnknown. Later, supplies came from Hevea of Brazil, generally known as Para rubber, and from Castilloc, sometimes called Central American Rubber, and from Munihot Glaziovii Ceara rubber. Not only are these plants now successfully enltivated in experimental gardens in the Tropies, but many other rubber-yielding. species have been added to the list. The Landolphias are among the most promising of the whole: these are the African rubbers. Now in addition to these which are the chief source of supply, we have Willughbeia, from the Malayan Peninsula, Leuconotis, Chilocarpus, Alstonin, Forsteronia, and a species of a genus formerly known as Urostigma, but now united with Ficus. These names, which have little significance as they are here pronounced in passing, are given now merely to impress upon our minds the fact that the sonrces of a single commercial article may be exceedingly diverse. Under these circumstances search is being made not only for the best varieties of these species but for new species as well.

There are few excursions in the 'l'ropics which possess greater interest to a botanist who cares for the industrial aspects of plants than the walks through the Gardens at Buitenzorg in Java and at Singapore. At both these stations the experimental Gardens lie at some distance from the great gardens which the tonrist is expected to visit, but the exertion well repays him for all discomfort. Under the almost vertical rays of the sun, are here gathered the rubber-yielding plants from different countries, all growing under conditions favorable for decisions as to their relative value. At Buitenzorg a well-equipped laboratory stands ready to answer practical questions as to quality and composition of their products, and year by year the search extends.

I mention this not as an isolated example of what is being accomplished in Commercial Botany, but as a fair illnstration of the thoronghness with which the problems are being attacked. It should be further stated that at the Garden in question assiduous students of the subject are eagerly welcomed and are provided with all needed appliances for carrying on technical, chemical and pharmacentical investigations. Therefore I am justified in saying that there is every reason for believing that in the very near future new sources of our most important products will be opened up, and new areas placed under snceessful cultivation.

At this point, attention must be called to a very modest and convenient handbook on the Commercial Botany of the Ninc- 
teenth Century by Mr. Jackson of the Botanical Museum attached to the Royal Gardens, Kew, which not only embodies a great amount of well-arranged information relative to the new nseful plants, but is, at the same time, a record of the existing state of things in all these departments of activity.

\section{ViII. Fragrant Plants.}

Another illnstration of our subject might be drawn from a class of plants which repays close study from a biological point of view, namely, those which yield perfumes.

In speaking of the future of our fragrant plants we must distinguish between those of commercial value and those of purely horticultural interest. The former will be less and less enltivated in proportion as synthetic chemistry by its manufacture of perfumes replaces the natural by the artificial products, for example, Conmarin, Vanillin, Nerolin, Heliotropiu, and even Oil of Wintergreen.

But do not understand me as intimating that Chemistry can ever furnish substitutes for living fragrant plants. Our gardens will always be sweetened by them, and the possibilities in this direction will continue to extend both by contributions from abroad and by improvement in our present cultivated varieties. Among the foreign acquisitions are the fragrant species of Andropogon. Who would suspect that the tropical relatives of our saud-loving grasses are of high commercial value as sources of perfumery oils?

The utility to the plant of fragrance in the flower and the relation of this to cross-fertilization, are apparent to even a casual observer. But the fragrance of an aromatic leaf does not always give us the reason for its being.

It has been suggested for certain cases that the volatile oils escaping from the plants in question may, by absorption, exert a direct influence in mitigating the fierceness of action of the sun's rays. Other explanations have also been made, some of which are even more fanciful than the last.

When, however, one has seen that the aromatic plants of Australia are almost free from attacks of insects and fungi, and has learned to look on the impregnating substances in some cases as protective against predatory insects and small foes of all kinds, and in others as fungicidal, he is tempted to ask whether all the substances of marked odor which we find in certain groups of plants may not play a similar rôle.

It is a fact of great interest to the surgeon that in many plants there is associated with the fragrant principle a marked antiseptic or fungicidal quality; conspicnous examples of this are afforded by species of Eucalyptus, yielding Eucalyptol, Styrax, yielding Styrone, Thymus yielding Thymol. It is inter- 
esting to note, too, that some of these most modern antiseptics were important constituents in the balsamic vulneraries of the earliest surgery.

\section{Florists' Plants.}

Florists' plants and the floral fashions of the future constitute an engaging subject which we can touch only lightly. It is reasonably clear that while the old favorite species will hold their ground in the guise of improved varieties, the new introductions will come in the shape of plants with flowering branches which retain their blossoms for a somewhat long period, and especially those in which the flowers precede the leaves. In short the next real fashion in our gardens is probably to be the flowering shrub and flowering tree, like those which are such favorites in the country from which the Western world has gladly taken the gift of the Chrysanthemum. ${ }^{29}$

Twice each year of late, a reception has been held by the Emperor and Empress of Japan. The receptions are in autumn and in the spring. That in the autumn, popularly known as the Emperor's reception, has for its floral decorations the myriad forms of the national flower, the chrysanthemum; that which is given in spring, the Empress' reception, comes when the cherry blossoms are at their best. One has little idea of the wealth of beanty in masses of flowering shrubs and trees, until he has seen the floral displays in the Imperial Gardens and the Temple grounds in Tokio.

To Japan ${ }^{29}$ and China also, we are indebted for many of the choicest plants of our gardens, but the supply of species is by no means exhausted. By far the larger number of the desirable plants have already found their way into the hands of cultivators, but often under conditions which have restricted their dissemination through the flower-loving community. There are many which ought to be widely known, especially the fascinating dwarf shrubs and dwarf trees of the far East, which are sure to find sooner or later a warm welcome among us.

\section{Forage Plants.}

Next to the food plants for man, there is no single class of commercial plants of greater interest than the food-plants for flocks and herds. Forage plants, wild and cultivated, are among the most important and highly valued resources of vast areas. No single question is of more vital consequence to our farthest west and southwest.

It so happens that the plants on which the pastoralist relies grow or are grown on soil of inferior value to the agriculturist. Even soil which is almost sterile may possess vegetation on which flocks and herds may graze, and, further, these animals may thrive in districts where the vegetation appears at first 
sight too scanty or too forbidding, even to support life. There are immense districts in parts of the Australian continent where flocks are kept on plants so dry and desert-like that an inexperienced person would pass them by as not fit for his sheep, and yet, as Mr. Sammel Dixon ${ }^{30}$ has well shown, these plants are of high nutritive value and are attractive to flocks.

Relegating to the notes to be published with this address brief descriptions of a few of the fodder plants suggested for use in dry districts, I shall now mention the salt-bushes of various sorts, and the allied desert plants of Australia as worth a careful trial on some of our very dry regions in the farthest west. There are numerous other excellent fodder plants adapted to dry but not parched areas which can be bronght in from the corresponding districts of the sonthern hemisphere and from the East.

At an earlicr stage of this address, $I$ have had occasion to refer to Baron von Mueller, whose efforts looking towards the introduction of useful plants into Australasia have been aided largely by his convenient treatise on economic plants. ${ }^{\circ}$ It may be said in connection with the fodder plants, especially, that much which the Baron has written can be applied mutatis mutandis to parts of onr own country.

The important subject of introducing fodder plants has been purposely reserved to the last because it permits us to examine a practical point of great interest. This is the caution which it is thonght necessary to exercise when a species is transferred by our own choice from one country to another. I say, by our choice, for whether we wish it or not certain plants will introduce themselves. In these days of frequent and intimate intercommunication between different countries, the exclusion of foreign plants' is simply impossible. Onr common weeds are striking illustrations of the readiness with which plants of one country make for themselves a home in another. ${ }^{31}$ All but two of the prominent weeds of the eastern States are foreign intruders.

There are all grades of persistence in these immigrants. Near the ballast grounds of every harbor, or the fields close by woolen and paper mills where foreign stock is used, yon will observe many foreign plants which have been introduced by seed. For many of these you will search in vain a second year. A few others persist for a year or two longer, but with uncertain tenure of the land which they have invaded: others still have come to stay. But happily some of the intruders which seem at first to gain a firm foot-hold, lose their ground after a while. We have a conspicnous example of this in a hawkweed, which was very threatening in New England two years ago, but is now relaxing its hold. 
Another illustration is afforded by a water-plant which we have given to the old world. This plant, called in our botanies Anacharis, or Elodea, is so far as I am aware, not troublesome in our ponds and water-ways, but when it was carried to England, perhaps as a plant for the aquarium, it was thrown into streams and rivers with a free hand. It spread with remarkable rapidity and became such an nnmitigated nuisance that it was called a curse. Efforts to extirpate it merely increased its rate of growtl. Its days of mischief are however nearly over, or seem to be drawing to a close, at least so Mr. Lynch of the Botanic Garden in Cambridge, England, and others of my informants think. The history of the plant shows that even under conditions which so far as we can see, are identical with those nnder which the plant grew in its horne, it may for a time take a fresh lease of life and thrive with an undreamed-of energy.

What did Anchcharis find in the waters of England and the continent that it did not have at home, and why should its energy begin to wane now ?

In Australasia one of the most striking of these intruders is Sweet-briar. Introduced as a hedge plant it has run over certain lands like a weed, and disputes every acre of some arable plats. From the facility with which it is propagated, it is almost ineradicable. There is something astounding in the Inanner in which it gains and holds its ground. Gorse and brambles and thistles are troublesome in some localities, and they prore much less easy to control than in Europe. The effect produced on the mind of the colonist by these intruding pests, is everywhere the same. Whenever in an examination of the plants likely to be worthy of trial in our American dry lands, the subject was mentioned by me to Anstralians, I was always enjoined to be cautious as to what plants I might suggest for introduction from their country into our orm. .My good friends insisted that it was bad enough to have as pests the plants which come in without our planning or choice, and this caution seems to me one which should not be forgotten.

It would take us too far from our patl to inquire what can be the possible reasons for such increase of vigor and fertility in plants which are transferred to a new home. We shonld have to examine all the suggestions which have been made, such as fresh soil, new skies, more efficient animal friends, or less destructive enemies. We shonld be obliged also to see whether the possible wearing out of the energy of some of these plants after a time, might not be attributable to the decadence of vigor through minterrupted bud-propagation, and we should have to allude to many other questions allied to these. But for this time fails. 
Lack of time also renders it impossible to deal with the questions which attach themselves to our main question, especially as to the limits of effect which cultivation may produce. We cannot touch the problem of inheritance of acquired peculiarities, or the manner in which cultivation predisposes the plant to innumerable modifications. Two of these modifications may be mentioned in passing, because they serve to exemplify the practical character of our subject.

Cultivation brings about in plants very curious morphological changes. For example, in the case of a well known vegetable the number of metamorphosed type-leaves forming the ovary is two, and yet under cultivation, the number increases irregularly until the full number of units in the type of the flower is reached. Professor Bailey of Cornell has called attention to some further interesting changes in the tomato, but the one mentioned suffices to illustrate the direction of variation which plants under cultivation are apt to take. Monstrosities are very apt to occur in cultivated plants, and under certain conditions may be perpetuated in succeeding generations, thus widening the field from which utilizable plants may be taken.

Another case of change produced by cultivation is likewise as yet wholly mexplained, although much studied, namely the mutual interaction of scion and stock in grafting, budding, and the like. It is probable that a further investigation of this subject may yet throw light on new possibilities in plants.

We have now arrived at the most practical question of all, namely-

In what way can the range of commercial botany be extended? In what manner or by what means can the introduction of new species be hastened?

It is possible that some of you are aware of the great amount of uncoördinated work which has been done and is now in hand in the direction of bringing in new plants.

The competition between the importers of new plants is so great both in the Old World and the New that a very large proportion of the species which would naturally commend them. selves for the use of florists, for the adornment of greenhouses, or for commercial ends, have been at one time or another brought before the public or are being accumulated in stock. The same is true although to a less extent with regard to useful vegetables and fruit. Hardly one of those which we can suggest as desirable for trial, has not already been investigated in Europe or this country, and reported on. The pages of our chemical, pharmacentical, medical, horticultural, agricultural and trade journals, especially those of high grade, contain a wealth of material of this character. 
But what is needed is this, that the promising plants should be systematically investigated under exhaustive conditions. It is not enough that an enthusiast here, or an amateur there should give a plant a trial under imperfectly understood conditions, and then report success or failure. The work should be thorough and every question answered categorically, so that we might be placed in possession of all the facts relative to the object experimented upon. But such an undertaking requires the coöperation of many different agencies. I shall venture to mention some of these.

In the first place,-Botanic Gardens amply endowed for research. The Arnold Arboretum, the Shaw Garden, and the Washington Experimental Garden, are American illustrations of what is needed for this purpose. University gardens have their place in instruction, but cannot wisely undertake this kind of work.

In the second place,-Museums and Laboratories of Economic Botany. Much good work in this direction has been done in this country by the National Museum and by the department in charge ${ }^{33}$ of the investigation of new plants. We need institutions like those at Kew in England, and at Buitenzorg in Java, which keep in close touch with all the world. The founding of an establishment on a scale of magnitude commensurate with the grcatness and needs of our country is an undertaking which waits for some one of our wealthy men.

In the third place,-Experiment Stations. These may, within the proper limits of their sphere of action, extend the study of plants beyond the established varieties to the species, and beyond the species to equivalent species in other genera. It is a matter of regret that so much of the energy displayed in these stations in this country, and we may say abroad, has not been more economically directed.

Great economy of energy must result from the recent change by which coördination of action is assured. The influence which the stations must exert on the welfare of our country, and the development of its resources is incalculable.

In the last place, but by no means least, the coöperation of all who are interested in scientific matters, through their observation of isolated and associated phenomena connected with plants of supposed utility, and by the cultivation of such plants by private individuals, unconnected with any State, governmental, or academic institutions.

By these agencies, wisely directed and energetically employed, the domains of commercial and industrial botan 5 , will be enlarged. To some of the possible results in these domains, I have endeavored to call your attention. 


\section{Notes.}

${ }^{0}$ The following are among the more useful works of a general character, dealing with the subject. Others are referred to either in the text or notes. The reader may consult also the list of works on Economic Botany in the catalogue published by the Linnæan Society.

Select Extra-tropical Plants, readily eligible for iudustrial culture or naturaliza. tion, with indications of their native countries and some of their uses. By BARON Ferd. yon MUeller, K.C.M.G., F.R.S., etc, Government Botanist for Victoria. (Melbourne), 1888. Seventh edition. revised and enlarged.

At the close of his treatise on industrial plants, Baron von Mueller has grouped the genera indicating the different classes of useful products in such a manner that we can ascertain the respective numbers belonging to the genera. Of course many of these genera figure in more than one category. them.

He has also arranged the plants according to the countries naturally producing

Jseful Native Plants of Australia, (including Tasmania). By J. H. MaIDEN, F.L.S., Curator of the Technological Museum of New South Wales, Sydney. (Sydney), 1889.

See also note 19.

Handbook of Commercial Geography. By Geo. G. Chisholm, M.A., B.Sc. London, 1889.

New Commercial Plants with directions how to grow them to the best advantage. By Thomas Christy (London), Christy and Co.

Lictionary of popular names of the plants which furnish the natural and acquired wants of man. By JoHn SMITH, A.L.S. (London), 188?.

Cullivated Plants. Their propagation and improvement. By F. W. BurBage. (London), 1877.

The Wanderings of Plants and animals from their first home. By VICTOR Heun, edited by James Steven Stallybrass, (London) 1885.

Researches into the Early History of Marikind, and the Development of Civilizatiou. By EDWARD B. TrLor, D.C.L., LL.D., F.R.S., 1878.

1 The number of species of Phænogamia has been given by many writers as not far from 150,000. But the total number of species recognized by Bentham and Hooker in the Gencra Plantarum (Durand's Index) is 100,220, in 210 Natural Orders and 8,417 genera.

${ }_{2}$ Dr. E. Lewis Sturtevant, to whose kindness I am indebted for great assistance in the matter of references has placed at my disposal many of his notes on edible plants, etc. From his enumeration it appears that if we count all the plants which have been cultivated for food at one time or another, the list contains 1,192 species, but if we count all the plants which "either habitually or during famine periods are recorded to have been eaten," we obtain a list of no less than 4,690 species, or about three and one-half per cent of all known species of plants. But, as Sir Joseph Hooker has said, the products of many plants though eatable, are not fit to eat.

3 The Folk-Lore of Plants. By T. F. Thiselton Dyer, 1889.

${ }^{4}$ In Dr. Sturtevant's list. 88 species of Gramineæ are counted as food-plants under cultivation, while the number of species in this order which can be or have been utilized as food amounts to 146. Our smaller number 20 comprises only those which have been grown on a large scale anywhere.

5 "In Agricultural Museum at Poppelsdorf, 600 varieties are exhibited."

${ }^{6}$ E. L. S. in letter. Qusted from Seedsman's catalogue.

${ }^{7}$ The best account of the early history of these and other cultivated plants can be found in the classical work of De Candolle "Origine des Plantes Cultivées (Paris) translated in the International series. History of Cultivated Plants, (N. Y.) The reader should consult also DARWIN's Animals and Plants under. Domestication.

${ }^{8}$ Food-grains of India, A. H. CHURCH, London, 1886, p. 34. In this instructive work the reader will find much information regarding the less common articles of food Of Panicum frumentaceum Professor Georgeson states in a letter that it is grown in Japan for its grain which is used for food, but here would take rank as a fodder plant. 


\section{G. L. Goodale-Possibilities of Economic Botany.}

${ }^{9}$ In order to avoid possible misapprehension, it should be stated that there are a few persons who hold that at least some of our cereals, and other cultivated plants. for that matter. bave not undergone material improvement but are essentially unmodified progeny. Under this view, if we could look back into the farthest past, we should see our cereals growing wilà and in such admirable condition that we should unhesitatingly select them for immediate use. This extreme position is nntenable.

Again, there are a few extremists who hold that some plants under cultivation have reached their culminating point, and must now remain stationary or begin to retrograde.

${ }^{10}$ Gray's Botanical Text Book. Vols. i and ii.

11 A Selection from the Physiological and Horticultural Papers, published in the Transactions of the Royal and Horticultural Societies, by the late Tromas ANDREW KNIGHT, Esq., President of the Hort. Soc. London. (London) 1841.

12 Illustrations of the Manners and Customs and Condition of the North American Indians. By GEORGE CATLIN, London, 1876. A reprint of the account published in 1841 of travels in $1832-40$.

"Plate 278 is a party of Sioux, in bark canoes (purchased of the Chippewas), gathering the wild rice, which grows in immense fields around the shores of the rivers and lakes of these northern regions, and used by the Indians as an article of food. The mode of gathering it is curious and, as seen in the drawing, one woman paddles the canoe, whilst another with a stick in each hand, bends the rice over the canoe with one, and strikes it with the other, which shakes it into the canoe, which is constantly moving along until it is filled." Vol. ii, p. 208.

${ }^{13}$ Schliemann's carbonized specimens exhumed in Grecce are said to be "very hard, fine-grained, sharp, very flat on grooved side, different from any wheats now known." Am. Antiq., 1880, 66.

The carbonized grains in the Peabody Museum at Cambridge, Mass., are small.

${ }_{14}$ Prehistoric Times as illustrated by Ancient Remains and the manners and customs of modern savages. By JoHN LubBock, Bart., (New York), 4th edn., 1886.

"Three varieties of wheat were cultivated by the Lake Dwellers, who also possessed two kinds of barley and two of millet. Of these the most ancient and most important were the six-rowed barley and small "Lake Dwellers" wheat. The discovery of Egyptian wheat (Triticum turgidum), at Wangen and Robenhausen, is particularly interesting. Oats were cultivated during the bronze age, but are absent from all the stone age villages Rye was also unknowu," p. 216 .

"Wheat is most common. having been discovered at Merlen. Moosseedorf and Wangen. At the latter place, indeed. many bushels of it were found, the grains being in large thick lumps. In other cases, the grains are free, and without chaff. resembling our present wheat in size and form, while more rarely they are still in the ear." 115 species of plants have been identified. Heer, Keller.

${ }^{15}$ Les Plantes Potagères, Vilmorin, Faris. Translated into English under the direction of W. Robinson, Editor of the (London) "Garden," 1885, and entitled The Vegetable Garden.

${ }_{16}^{16}$ l. c., English Edn., p 104.

17 A ccording to notes made by Mr. Manning. Sec. Massachusetts Horticultural Society, (Hist. Mass. Hort. Socety) the tomato was introduced into Salem, Mass., about 1802 by Michele Felice Corné, an Italian painter, but he found it difficult to persuade people even to taste the fruit (Felt's Annals of Salem, vol. ii, 631). It was said to have been introduced into Philadelphia by a French refugee from San Domingo in 1798. It was used as an article of food in New Orleans in 1812 but was not sold in the markets of Philadelphia until 1829. It did not come into general use in the north until some years after the last named date.

15 '. In Spain and those hot regions, they use to eat the (Love) apples prepared and boiled with pepper, salt, and olives; but they yield very little nourishment to the bodies, and the same nought and corrupt. Likewise they doe eat the apples with oile, vinegar, and pepper mixed together for sauce to their meat even as we in these Cold Countries do Ni ustard." GERARD's Herbal, 346.

$\because 19$ Commercial Botany of the Nineteenth Century. By Jону R. JACrsos, A.L.S. Cassell and Company, London, 1890. 
Mr. Jackson, who is the Curator of the Museums, Royal Gardens, Kew, has embodied in this treatise a great amount of valuable information, well arranged for ready reference.

20 Department of Agriculture Report for 1870, p. 404-428. Only those are here copied from Dr. Palmer's list which he expressly states are extensively used.

Ground-nut (Apios tuberosa); Aesculus Californica; Agave Americana; Nuphar advena; Prairie-potato, (Psoralea esculenta); Scirpus lacustris; Sagiltaria variabilis; Kamass-root (Camassia esculenta); Solanum Fendleri (supposed by him to be the original of the cultivated potato); Acorns of various sort; Mesquite, (Algarobia glandulosa); Juniperus occidentalis; Nuts of Carya, Juglans, etc.; Screw-bean (Strombocarpus pubescens); various Cactaceæ; Iucca; Cherries and many wild berries; Chenopodium album, etc.

- Psoralea esculenta = prairie potato, or Bread-root. Palmer in Agl. Report, 1870 , p. 402.

The following from CATLiN, l. c., i, p. 122 :

"Coru and dried meat are generally laid in the fall, in sufficient quantities to support them through the winter. These are the principal articles of food during that long and inclement season; and in addition to them, they oftentimes have in store great quantities of dried squashes, and dried 'pommes blanches,' a kind of turnip which grows in great abnndance in those regions. . . . . These are dried in great quantities and pounded into a sort of meal and cooked with dried meat and corn. Great quantities also are dried and laid away in store for the winter season, such as buffalo berries, service berries, strawberries, and wild plums."

"In addition to this we had the luxury of service berries without stint; and the buffalo bushes, which are peculiar to these northern regions, lined the banks of the river and the defiles in the bluffs, sometimes for miles together, forming almost impassible hedges, so loaded with the weight of their fruit that their boughs everywhere gracefully bending down or resting on the ground. This last shrub (Shepherdia), which may be said to be the most beautiful ornament that decks out the wild prairies, forms a striking contrast to the rest of the foliage, from the blue appearance of its leaves by which it can be distinguished for miles in distance. The fruit which it produces in such incredible profusion, hanging in clusters to every limb and to every twig, is about the size of ordinary currants and not unlike them in color and even in flavor; being exceeding acid, almost unpalatable until they are bitten by frost of autumn, when they are sweetened and their flavor delicious, having to the taste much the character of grapes, and I am almost to think would produce excellent wine." GEORGE CATLIN's Illustralions and manners, customs, and condition of the North American Indians, p. 72, vol. i.

For much relative to the food of our aborigines, especially of the western coast, consult The Native Races of the Pacific States of North America. By H. H. Bancroft. (New York), 1875. The following from vol, i, p. 538, indicates that inaccuracies have crept into the work: "From the earliest information we have of these nations" (the author is speaking of the New Mexicans), " they are known to have been tillers of the soil; and though the implements used and their methods of cultivation were both simple and primitive, cotton, corn, wheat, beans, and many varieties of fruits which constituted their principal food were raised in abundanct."

Wheat was not grown on the American continent until after the landing of the first explorers.

${ }^{21}$ Gard. Chron., 1888.

${ }^{22}$ Pickled Daikon, the large radish, often grated.

Ginger-roots-Shoga.

Beans (Glycine hispida), many kinds, and prepared in many ways.

Beans (Dolichos cultratus), cooked in rice and mixed with it.

Sliced Hasu, Lotos roots.

Lily bulbs, boiled whole and the scales torn off as they are eaten.

Pickled green plums, (Ume-boshi) colored red in the pickle, by the leaves of Perilla arguta (Shiso).

Sliced and dried cucumbers, Kiuri.

Pieces of Gobo,-Roots of Lappa major. 


\section{G. L. Goodale-I'ossibilities of Economic Botany. 303}

Rakkio,-Bulbs of Allium Bakeri, boiled in Shogu.

Grated Wasabi,_Stem of Eutrema Wasabi.

Water-cress, - Midzu-tagarashi (not often).

Also sometimes pickled greens of various kinds, and occasionally chestnut-

kernels boiled and mixed with a kind of sweet sauce.

Nut of the Ginkgo tree.

Several kinds of seaweeds are also very commonly served with the rice. Pro-

fessor C. C. Georgeson in letter.

${ }^{23}$ l. c. Preface in English Edition.

24 "Carbonized apples have been found at Wangen, sometimes whole, some. times cut in two, or, more rarely, into four pieces and evidently dried and put aside for winter use...... They are small and generally resemble those which still grow wild in the Swiss forests; at Robenhausen, however, specimens have occurred which are of larger size, and probably cultivated. No trace of the vine, the walnut, the cherry, or the damsou has yet been met with, but stones of the wild plum and the Pr unus padus have been found." Luввоск, l.c., p. 217.

${ }_{25}$ Animals and Plants under Domestication (Am. Edn.), vol. il, p. 205-209.

${ }_{26}$ American Garden, N. Y. 1890-91.

${ }^{27}$ American Garden, N. Y. 1891.

${ }^{28}$ Useful Native Plants of Australia, by J. H. MAIDEN, Sydney.

${ }^{29}$ The Flowers of Japan and the Art of Floral Arraugement. By JOSIAH CONDER, F.R.I.B.A., Arehitect to the Imperial Japanese Government. Yokohama, 1891. See also two other works by the same author: Theory of Japanese Flowerarrangements, and Art of Landscape-gardening in Japan. (1886.)

30 Mr. Samuer Dixon's list is in vol. viii (for 1884-85) of the Transactions and Prociedings and Report of the Royal Society of South Australia. Adelaide, G. Robertson, 1886.

Bursaria spinosa, "a good stand-by," after the grasses dry up.

Pomaderris racemosa, "stands stocking well."

Pittosporum phyllaeroides, "sheep exceedingly partial to its foliage."

Casuarina quadrivalvis, "tenderness of fiber, wool would be represented by it in our finer wool districts."

Acacias, The Wattles. "Value as an astringent, very great," being curative of a malady often caused by eating frozen grass.

Acacia aneura (mulga). "Must be very nutritious to all animals eating it." This is the plant which is such a terror to the stockmen who have to ride through the "scrub."

Cassia, some of the species with good pods and leaves for sheep.

The foregoing are found in districts which are not wholly arid.

The following are, more properly, "dry" plants.

Sida petrophila, "as much liked by sheep as by marsupials."

Dodonaea viscosa, Native Hop-bush. "Likes warm, red, sandy ground."

Lycium australe, "Drought never seems to affect it."

Kochia aphylla: "All kinds of stock are often largely dependent on it during protracted droughts."

Rhagodia parabolica: "Produces a good deal of foliage."

Atriplex vesicaria: "Can be readily grown wherever the climate is not too wet."

I have transferred only those which Mr. Dixon thinks most worthy of trial. Compare also Dr. VASEY'S valuable studies of the plants of our dry lands, especially Grasses and Forage plants (1878), Grasses of the arid districts of Kansas, Nebraska, and Colorado (1886), Grasses of the South (1887.

${ }_{31}$ The weeds of German gardens and agricultural lands are mostly from Medi. terranean regions, but the invasions in the uncultivated districts are chiefly from America, (such as Oenothera, Mimulus, Rudbeckia). Handbuch der Pfanzengeographre, von Dr. OSCAR DRUDE, (Stuttgart), 1890, p. 97.

33 The list of economic plants publisher by the Department in Washington is remarkably full, and is in every way creditable to those in charge. 


LIBRARY OF CONGRESS
LIHI

0.0027629556

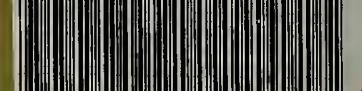

